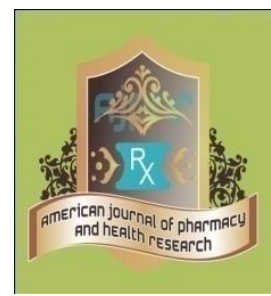
Review Article
AMERICAN JOURNAL OF PHARMACY AND HEALTH RESEARCH www.ajphr.com 2020, Volume 8, Issue 08 ISSN: 2321-3647(online)

\title{
Suddab (Ruta graveolens Linn.) the Blessed Medicinal plant of Unani System of medicine: Literature Review.
}

\author{
Md. Shams Reza1, Md. Razi Ahmad², Md Najibur Rahman ${ }^{3}$, Md Tanwir Alam* \\ 1.BUMS, Unani Practitioner, Sheohar, Bihar \\ 2.Lecturer Dept. of Niswa wa Qabalah, Govt. Tibbi College \& Hospital, Patna, Bihar. \\ 3.Lecturer Dept. of Moalajat, Govt. Tibbi College \& Hospital, Patna, Bihar. \\ 4.Lecturer Dept. of PSM, Govt. Tibbi College \& Hospital, Patna, Bihar.
}

\begin{abstract}
Plant of Suddab is commonly cultivated in Indian gardens. The whole plant of Suddab has medicinal value hence used in various diseases and included as an ingredient in a number of formulations. However, its two parts i.e. leaves and seeds are more commonly used. The plant as whole has described to possess Mudir (diuretic), Kasir riyah (carminative), Muhallil and Dafe Alam (analgesic) properties and useful in a number of diverse pathological conditions. In some parts of India, the juice is given to children as a remedy for worms. The use of Suddab since ancient times in different alternative system of medicine like Unani, Ayurveda in single as well as many compound formulations for the treatment of Obesity (Saman-e-Mufrat), Dyslipidemia (Fart-eTadassum-Fid-Dum), Atherosclerosis (Salabat-E-Nabz), Anti-helminthic (Deedan-e-medad wa amma) Muhallil and Dafe Alam (Anti-inflammatory \& analgesic) etc. Several studies have been carried out for the therapeutic evaluation of its efficacy and safety. So, I want to compile and summarized all the literature at one space.
\end{abstract}

Keywords: Suddab; Saman-e-Mufrat; Salabt-e-Nabz; Deedan-e-medad wa amma; Muhallil; Dafe Alam.

*Corresponding Author Email: tanveernium3133@gmail.com

Received 10 July 2020, Accepted 19 August 2020

Please cite this article as: Alam T et al., Suddab (Ruta graveolens Linn.) the Blessed Medicinal plant of Unani System of medicine: Literature Review. American Journal of Pharmacy \& Health Research 2020. 


\section{INTRODUCTION}

Suddab (Ruta graveolens Linn.) is an herb with an ancient history. The genus name 'Ruta' comes from the Greek word 'reuo', to set free, showing its reputation as a freer from disease. Leaves are abortifacient, anthelmintic, antiepileptic, anti-inflammatory, carminative, emetic, emmenagogue, expectorant, haemostatic, nervine, rubefacient and mildly stomachic. The herb is also considered antispasmodic, diuretic, resolvent and strongly stimulant. It is used as a stimulant to the nervous system and uterus. Useful in skin disorders, cramps in the bowel and hysteria. It is chiefly used to encourage the onset of menstruation and as a remedy for menstrual disorders such as PMS. It stimulates the muscles of the uterus and promotes menstrual blood flow. It also strengthens the stomach, aids digestion and is useful in sluggish liver. The herb is also used to ease colic and reduce flatulence. The herb was prescribed in cases of vertigo and epilepsy in the $17^{\text {th }}$ century ${ }^{1,2}$, 3,4 .

Many of Rue's positive benefits can be traced to its high concentration of the bioflavonoid, Rutin. Among other benefits, Rutin is known to strengthen blood vessels, thus reducing the likelihood of varicose veins, and improving overall cardiovascular function.

\section{MATERIALS AND METHOD}

Review material collected from the different ancient Unani books, PG Dissertation, online authentic research Journals \& different websites and summarized with the help of computer.

\section{Description in Unani Literature}

Two varities of Suddab have been described in Unani literature (a) Bustani (b) Jangli. The stem of Bustani is short and different branches arise from it. Flowers grow in its branches; leaves are short and light golden in colour. Fruits present at its branches in the form of cluster. Usually four seeds are found in fruits. The leaves of Jangli Suddab are shorter as compared to Bustani Suddab but size of flower is same ${ }^{5,6}$.

\section{Botanical Description}

There are three varieties of Suddab; garden, forest and mountain. A perennial herbaceous or half shrub by plant, reaching 2 or 2.5 feet in height. Stems cylindrical, slender, branched in the upper part, quite smooth, pale glaucous green, somewhat shrubby at the base, and covered with a grey bark. Leaves alternate, without stipules, compound, the lower ones tripinnate, the upper one's sub bi-pinnate or pinnate, the highest simple, leaflets linear oval or oblong, the terminal ones obovate, all dotted with small pellucid glands, rather thick bluish green. Inflorescence a terminal corymbose irregularly trichotomous cyme. Flowers on long stalks, erect nearly an inch across. Calyx of 4 or 5 sepal, slightly connected, narrow, acute semi persistent. Petals alternating with the sepal's which 
they greatly exceed, distant widely spreading, greenish yellow, wide and hooded at the top, suddenly contracted into a narrow claw below, the margin more or less wavy and sometime toothed $4,6,7$.

$\begin{array}{lll}\text { Synonyms: }{ }^{4,6,8,9} . & & \\ \text { Botanical Name } & : & \text { Ruta graveolens Linn. } \\ \text { Family } & : & \text { Rutaceae } \\ \text { English } & : & \text { The Garden Rue, Common Rue. } \\ \text { Arabic } & : & \text { Suddab } \\ \text { Hindi } & : & \text { Pismarum, Saddab } \\ \text { Sanskrit } & : & \text { Sadapaha } \\ \text { Persian } & : & \text { Sadab } \\ \text { Malayalam } & : & \text { Aruta Somarayen. } \\ \text { Bengali } & : & \text { Title } \\ \text { Marathi } & : & \text { Satap }\end{array}$

\section{Habitat and Distribution}

Plants of Suddab are found in all parts of India both cultivated and wild ${ }^{8,9,10}$.
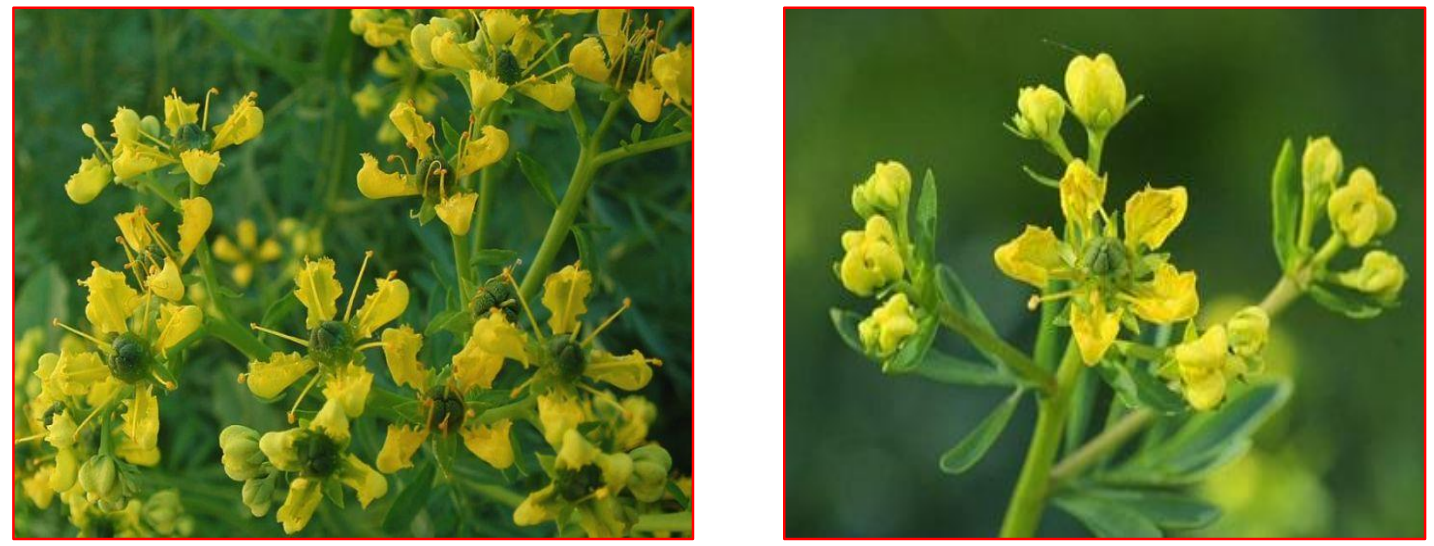

\section{Pharmacognosy:}

Stamens twice as many as the petals, 8 or 10 inserted below the hypogynous disk, half opposite the petal, in the concave limbs of which they are at first contained; filaments slender glabrous at the length straight and exceeding the petals. Pestil surrounded at the asile and supported by a thick fleshy green sticky disk, marked opposite each stamen with a deep nectariferous pore; ovary large 4 or 5 lobed, the lobes (carpels) separate above strongly dotted with sunk glands 4 celled ovules numerous on axile placentas; styles coming off from the inner side of the carpels, combined into a single body tapering to the apical stigmas. Fruit dry hard roundish 4 or 5 lobed at top, grayish brown rough each carpel descending from above ventrally and also for some way down the dorsal 
suture. Seeds ovoid, rounded on the back flattish in front angular blackish rough; embryo slightly curved from base to apex surrounded by scanty fleshy endosperm. The central terminal flowers of the corymbs are usually 5 merous the other generally 4 merous ${ }^{4,6,11,12}$.

\section{Chemical constituents:}

Furanocoumarins, 7-hydroxycoumarin, 4-methyl and 8-methyl derivatives, rutaretin.

Mizaj (Temperament): Hot and Dry $2^{\text {nd }} \operatorname{degree}^{9,10}$.

Hot and Dry $3^{\text {rd }}$ degree $2,9,13$.

Hot and Dry $4^{\text {th }}$ degree. (Wild Variety) $)^{8,9,14}$.

Parts used: Suddab leaves.

\section{Functions and Uses}

Anticonvulsive (Dafe-tashannuj), Antiseptic (Dafe-taffun), Appetizer (Mushtahi), Astringent (Mujaffif), Antispasmodic (Dafe-tamaddud), Contraceptive (Mane Haml), Diuretic (Mudir -eBaul), Emmenagouge (Mudir-e-Haiz), Nervine Tonic (Muqawwi-e-Aasab), Febrifuge (DafeHumma), Anthelmintic (Qatil-e-deedan), Deobstruent (Radae), Alexipharmic(Tiryaaq-eSamoom), Resolvent (Muhallil), Remover (Qate), Sediative (Munawwim), Demulscent (Mulattif), Desiscent (Mujaffif) $)^{2,3,6,8,9,15}$.

\section{Therapeutic Uses}

It is used in GIT disorders such as indigestion, flatulence etc owing its Muhallil, Musakkin, and Kasir riyah properties. This drug is used in the management of Samane Mufrat, Farte-Tadassumfid-dam, Salat-e-Nabz, Wajaul Mafasil (Arthritis), Niqras (Gout), and Irqunnisa (Sciatica). It is also used in Istesqa (Ascitis) and Tahabbuj (Oedema) The herb and oil act as stimulant, their influence being chiefly directed to uterine and nervous systems. Rue has also been regarded as anthelmintic and in excessive doses it is an acro-narcotic poison. Rue was formerly much employed, but it is rearly prescribed at present day, although rue tea is still a popular remedy. It may be given in Hysteria, Amenorrhea, Epilepsy, Flatulent colic, Infantile convulsions etc, and appears to have fallen too much into disuse. The oil is the best form of administration; it may also be used externally as a rubefacient. 4,6,7,8,9,10,11,12,13,14,16,17,18, 19,20,21,22,23,24.

Dosage: $3 \mathrm{gm}$ to $5 \mathrm{gm}^{11}$.

Muzir (Adverse effects): Muzefe Basar and Musdde ${ }^{3}$.

\section{Side Effects:}

Continuous exposure causes Inflammation all over the body. Over dosage may cause Migraine, Nausea and Vomiting. It is also caused defective eye sight, Sexual debility, Vertigo, Headache, Flushing of face and harmful effect on cardiovascular system. Its inhalation can be cause Dizziness 
and Blurring of mind and it's also burned the Humor including seminal fluid. Dry and wet Itching $^{4,12,18}$.

Corrective: Sikanjabeen and Aneesun ${ }^{3}$.

Alternative: Satar Farsi

Important formulations:

Safoof Sailaan-ur-Raham, Safoof-e-Salab, Majoon Halteet, Jawarish Kamooni, Safoof-e-Mohazzil

Scientific reports: It has been reported that $S u d d a b$ has anti-inflammatory activity ${ }^{18}$, anti-lipid, anti-atherosclerotic, Moqawwi-e-hazam.

\section{ACKNOWLEDGEMENT}

Authors acknowledge all the scholar, writer and scientist whose reference has been cited in this review article.

\section{REFERENCES}

1. http://www.hashmidawakhana.co.in/ruta-graveolenslinn.html\#: :text=Berge\%20Suddab\%2C\%20Sudapa\%2C\%20Garden\%20Rue,15\%20Im pressive\%20Benefits\%20of\%20Fennel (Cited on 15/06/2020)

2. Ghani N. Qarabadeen-e-Najmul-Ghani. Munshi Nawal Kishore, Lucknow. 1938: 402.

3. Razi ABMZ. Al-Haavi-Al-Kabeer, Daira-al-Maarif. $1^{\text {st }}$ edi. Vol. 21 ${ }^{\text {st }} .1967: 135$.

4. Nadakarni. Indian Material Medica, Popular Parkashan, Bombay. Vol $2^{\text {nd }}, 1976: 103-04$.

5. Baitar I. Kitab-al-jami-ul-Mufradat-Advia-Wal-Aghzia. Ammara press, Egypt. Vol $2^{\text {nd }} \&$ $4^{\text {th }}, 1272 H ; 125$, part 3, CCRUM. 1999: 27.

6. Kartikar KR \& Basu RD. Indian Medicinal Plants, L.M. Basu, Allahabad, Vol $2^{\text {nd }}$. 1918:1201.

7. Bentley R \& Trimen H. Medicinal plant, PEB agency and International book distributors, Delhi, Asiatic publishing house Delhi, 2002, Vol $4^{\text {th }} 1983: 120,123$.

8. Hassan M. Tauzih-ul-Advia. Mataba Gulzare Mohammadi, Meerut. 1894:17.

9. Hussain M. Makhzanul-Advia. Munshi Gulab Singh, Lucknow. 1892: 224.

10. Momin MH. Tohfat-ul-Momenin. Mataba Hasani, Lucknow. 1874: 39.

11. Lubhaya R. Goswami Bayan-ul-Advia. Goswami Pharmacy, Gali Qasim Jan, Delhi. Vol $1^{\text {st }} .1984: 93$.

12. Annonymous. Wealth of India, Raw material, Council of scientific and industrial research New Delhi, Vol $1^{\text {st }} .1948:$ 106-07.

13. Khan MH. Tafhim-ul-Advia. Maktaba Munshi Nawal Kishore, Kanpur. 1882: 13.

14. Hakim MA. Bustanul-Mufadat. Indara Taraqqi Urdu Publication, Lucknow. 1895:86. 
15. Gani N. Khazainul Advia. Idara Kitabul Shifa, New Delhi. YNM: 401-02.

16. Ahmed J. Talim-ul-Advia. Nami press, Lucknow. 1936: 25.

17. Gazrooni MS. Al-Sadidee. Mataba Nami, Lucknow. 1925: 183.

18. Ratheesh M \& Helen A. Anti-inflammatory activity of Ruta graveolens Linn. on carrageenan induced paw oedema in waster male rats. Indian African Journal of Biochemistry. 1209-1211.

19. Ahmad L. Scientific Evaluation of Safoof-e-Mohazzil- a Compound Unani Formulation, P.G. Dissertation, AKTCH, Dept. of Ilmul-Advia, Faculty of Unani Medicine, AMU. Aligarh, 2000.

20. Shahabuddin. Clinical Study of Farte Tadassum Fiddam and Evaluation of Efficacy of Unani Formulation in its Management, P.G. Dissertation, Submitted to RGUHS, Dept. of Moalajat, NIUM Bangalore. 2008.

21. Sayyed Minhaj. Clinical Study of Samane Mufrat Ibtedai and Efficacy of Unani Formulation in its Management, P.G. Dissertation, Submitted to RGUHS, Dept. of Moalajat, NIUM Bangalore. 2008.

22. Md Razi Ahmad. A Prospective open label randomized clinical study of Safoof-e-Mohazzil in the cases of Primary Hyperlipidaemia (Fart-e-Tadassum-Fid-Dam)., P.G. Dissertation, Submitted to MUHS Nashik, Dept. of Moalajat, ZVM Unani Medical College \& Hospital Pune. 2011.

23. https://www.researchgate.net/publication/331431355_Efficacy_Of_Tukhm-E-

Suddab_Ruta_Graveolens_In_The_Management_Of_Salabat-E-

Nabz_Atherosclerosis_A_Randomized_Single_Blind_Placebo_Controlled_Clinical_Trial (Cited on 15/7/2020).

24. Ghani N. Qarabadeen-e-Najmul-Ghani. Munshi Nawal Kishore, Lucknow. 1938: 402, 651,701,736-37.

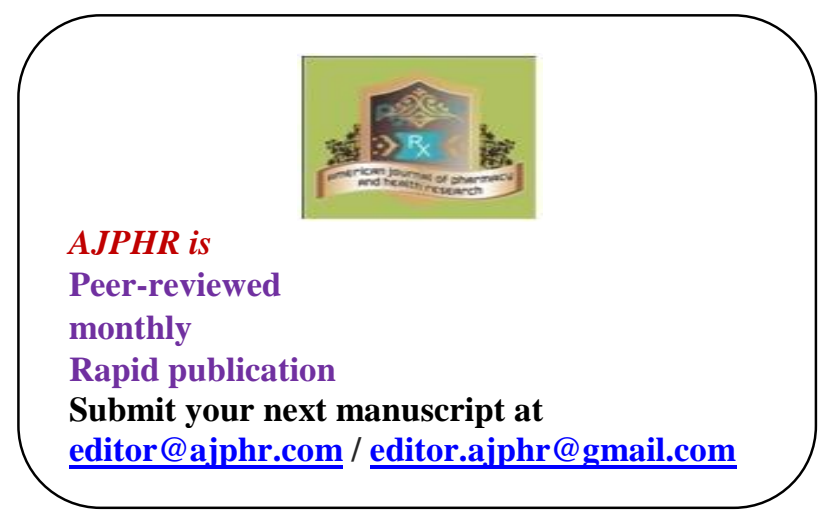

